ח

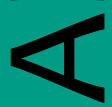

n

Ш

Z

O

$\underline{-}$

$F$

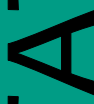

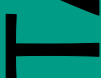

ه

Ш

n

n

$\overline{0}$
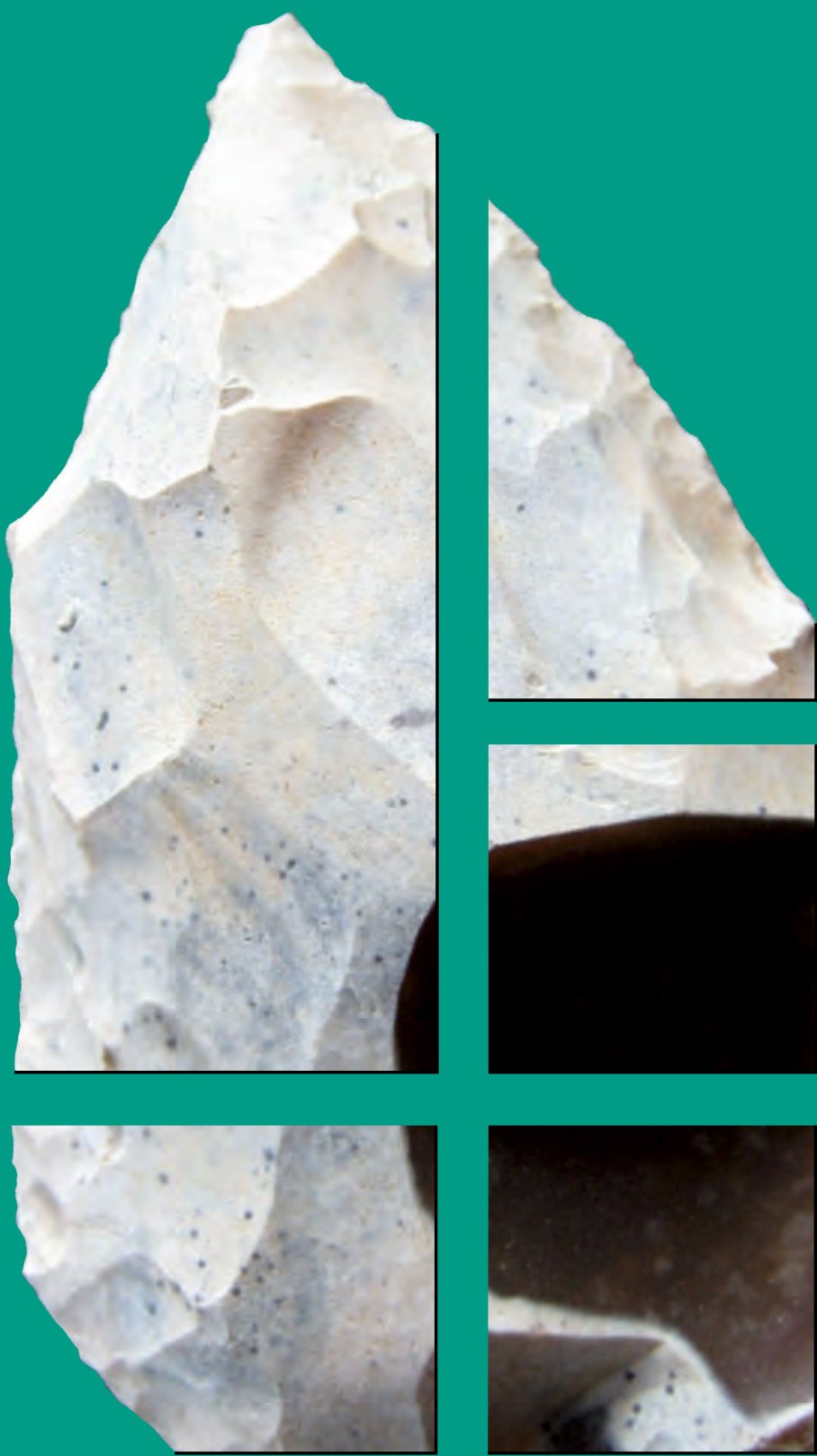

Ser. 3. No.9.| 2021 


\section{Dissertationes Archaeologicae ex Instituto Archaeologico}

Universitatis de Rolando Eötvös nominatae

Ser. 3. No. 9.

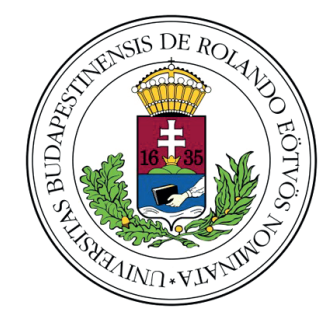

Budapest 2021 


\section{Dissertationes Archaeologicae ex Instituto Archaeologico Universitatis de Rolando Eötvös nominatae}

Ser. 3. No. 9.

Editor-in-chief

Dávid BARTus

Editorial board

László Bartosiewicz (Stockholm University, Stockholm)

Ondřej Chvojкa (University of South Bohemia, České Budějovice)

Zoltán Czajlik (Eötvös Loránd University, Budapest)

Mario Gavranović (Austrian Arhaeological Institute AAS, Vienna)

Hajnalka Herold (University of Exeter, Exeter)

Klára Kuzmová (University of Trnava, Trnava)

Tina Milavec (University of Ljubljana, Ljubljana)

Gábor V. Szabó (Eötvös Loránd University, Budapest)

Tivadar VIDA (Eötvös Loránd University, Budapest)

Technical editor

Gábor VÁcZI

Proofreading

Eszter TímÁr

Strobe DrIVER

Borbála MoHÁcsI

Fruzsina NÉMETH

Eli J. S. WeAVERDYCKE

Aviable online at http://ojs.elte.hu/dissarch

Contact: dissarch@btk.elte.hu

ISSN 2064-4574 (online)

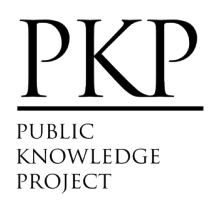

(c ELTE Eötvös Loránd University, Institute of Archaeological Sciences

Layout and cover design: Gábor Váczi

Budapest 2021 


\section{CONTEnTs}

\section{ARTiCles}

Attila PÉNTEK - Norbert FARAgó

Palaeolithic and Mesolithic assemblages from Tunisia

Attila PÉNTEK - Norbert FARAGó

Some remarks on a German chipped stone lithic assemblage of uncertain origin in the collection of the Institue of Archaeological Sciences, Eötvös Loránd University

László Gucsi

Technological observations on a Late Copper Age ceramic assemblage

from Hódmezővásárhely-Kopáncs-Olasz-tanya, Hungary

János Gábor TARBAY

101

A Koszider Period Sword from Tornyospálca-Sírkútgaz (Szabolcs-Szatmár-Bereg County, Hungary)

Ábel GARCZIK

Dolia in the Middle La Tène Period of the Carpathian Basin in the light of new finds from Perkáta-Nyúli-dűlő

Lajos JuHÁsz

An exceptional Sarmatian cast medallion with star and crescent

Gabriella G. DeLBó

New data on the Pannonian glazed casserole handles

Csilla SÁró

The fibula production of Brigetio: Model, semi-finished products, and failed castings

Anita BENES

New data on the capacity of the Roman aqueduct of Brigetio

Melinda SzABó

Status or Role? Differences between the Social Status and Role in Brigetio

Krisztina HoppáL

Roman engraved gems from Southeast Asia 


\section{FiELD REPORTS}

Bence SIMON - Ferenc BARNA

Another barrel-lined well a road section and late Roman graves from Brigetio

Rita RAKONCZAY

Trial excavations in mediaeval churches of Kishartyán, Kisterenye, Mátranovák and Szuha in Nógrád County 2021

\section{Thesis Review Articles}

Tamás KEszi

The change of the pottery style of the Mako and Nagyrév cultures in the Early Bronze Age:

The settlement in Iváncsa-Lapos

Linda Dobosi

Building techniques and building materials in Brigetio:

With the virtual reconstruction of House I/a of the civil town of Brigetio

Csilla SÁRó

Tradition and Romanization by the attire of the Eraviscus tribe 


\title{
A Koszider Period Sword from Tornyospálca-Sírkútgaz (Szabolcs-Szatmár-Bereg County, Hungary)
}

\author{
János Gábor TARBAY \\ Hungarian National Museum \\ Department of Archaeology \\ Prehistoric Collection \\ tarbay.gabor@hnm.hu
}

Received 21 July 2021 | Accepted 7 October 2021 | Published 2 March 2022

\begin{abstract}
The study discusses a metal-hilted sword from Tornyospálca-Sírkútgaz (Szabolcs-Szatmár-Bereg County, Hungary). This find is an "old debt" of local Bronze Age research since it was left unpublished in the prehistoric collection of the Hungarian National Museum for more than half a century following its accidental discovery in 1956. The Tornyospálca-Sírkútgaz sword is a unique weapon compared to other Middle Bronze Age (Koszider Period, Br B1) Carpathian weapons. The Valsømagle swords have a few related finds from this area and from the wider territory of Europe. This study introduces the weapon to the scientific public with a brief discussion of related finds and their relative chronological position. The production technology, use-wear traces, and the deposition condition of the Tornyospálca-Sírkútgaz sword have been studied by metalwork production and use-wear analysis, and the results are also compared to the swords and the dagger of the eponymous Zajta hoard (Szabolcs-Szatmár-Bereg County, Hungary).

Keywords: Middle Bronze Age (Br B1), use-wear analysis, Valsømagle type swords, Zajta hoard
\end{abstract}

\section{Introduction}

According to archive document No. XXII.389/1956 of the Hungarian National Museum (HNM), a bronze sword was found sometime in August 1956 in Tornyospálca-"Sírkútgaz" (Szabolcs-Szatmár-Bereg County, Hungary). The first report on the object was written by László Makkay, the director of the Kisvárda Museum [Rétközi Múzeum, Kisvárda], whose notes were forwarded by the colleagues of the Jósa András Museum in Nyíregyháza to the HNM. The find spot was also investigated by Tibor Kovács (HNM), who described the exact location of the object as well as the circumstances of its discovery. Based on his report, the bronze sword was found at a depth of about 15-20 cm by György Csizmadia, a tractor driver (Tornyospálca, Honvéd Street 49), during agricultural work in August 1956. The so-called 'Sirkutgaz' [Sirkut gaz dülő/Sírkútgaz] is situated ca. 800 metres west of Tornyospálca and 50 metres north of the Litke road, between the so-called Kónyahegy and "Urhegy" [Örhegy] mounds. Tibor Kovács opened a sondage (approx. half a metre deep) on the exact find-spot, but no further Bronze Age potsherds or bronze objects were found. He also noted that György Csizmadia was not entirely certain about the exact find spot, which was overgrown with corn (Figs 1-3). ${ }^{1}$ Therefore, it is very likely that the sondage was not opened on the exact find spot, and there may be further finds in the future. 
Unfortunately, after its discovery, the find was not published for over 65 years. As a result, this weapon was not included in the two seminal Prähistorische Bronzefunde volumes about Hungarian Bronze Age swords published by Tibor Kemenczei in 1988 and 1991. ${ }^{2}$ However, in 1973 and 1976, Amália Mozsolics noted it as an octagonal hilted sword (Achtkantschwert) with a schematic formal description and as a parallel to the Rimavská Sobota/Rimaszombat ones (Banská Bystrica Region, Slovakia). ${ }^{3}$ Finally, the object was mentioned in the work of Sándor Agárdi, who released a rough sketch and some further data about the circumstances of its discovery. According to him, the exact time of discovery was August 17, $1956 .{ }^{4}$

I "re-discovered" the sword during the revision of the Prehistoric Collection of the Hungarian National Museum in 2021. The find could be identified with the help of Sándor Agárdi's book and by the archive document No. XXII.389/1956 written by Tibor Kovács, which the colleagues of the HNM kindly allowed me to study: László Szende and Béla Debreczeni-Droppán.

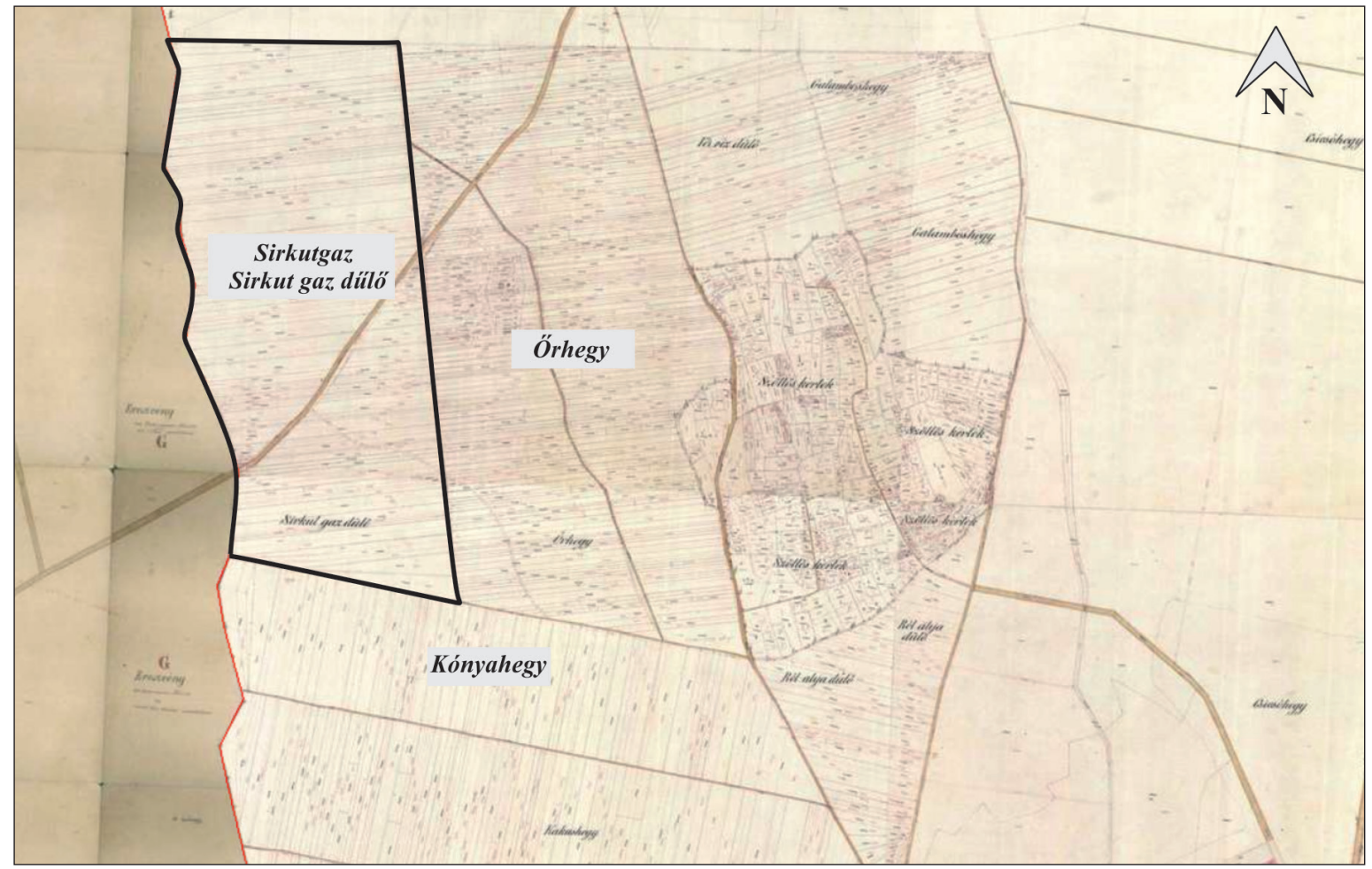

Fig. 1. The Tornyospálca-Sírkútgaz (Szabolcs-Szatmár-Bereg County, HU) on the Cadastral maps (19 ${ }^{\text {th }}$ century) of the Habsburg Empire.

\section{Description}

The Tornyospálca-Sírkútgaz sword (HNM 2021.10.1) has an oval-sectioned metal hilt, which thickens towards the end. Its pommel is slightly convex and has an emphasized rim. The shoulders of the metal hilt are decorated on both sides with six pseudo rivets (Fig. 2,2). The sword has a long, straight, and slightly rhomboid-sectioned blade, which is decorated with two irregularly outlined grooves (Figs 2-3). Dimensions: Total length $638.4 \mathrm{~mm}$; length (hilt) $113.84 \mathrm{~mm}$; length (blade) $525 \mathrm{~mm}$; diameter (pommel) $41.57 \times 29.98 \mathrm{~mm}$; diameter (hilt) $30.47 \times 25.27 \mathrm{~mm}, 25.18 \times 14.32 \mathrm{~mm}$; width (shoulders of the hilt) $59.50 \mathrm{~mm}$; width (blade) 35.58-35.06 mm; thickness (blade) $6.25 \mathrm{~mm}$; weight $678.5 \mathrm{~g}$. 


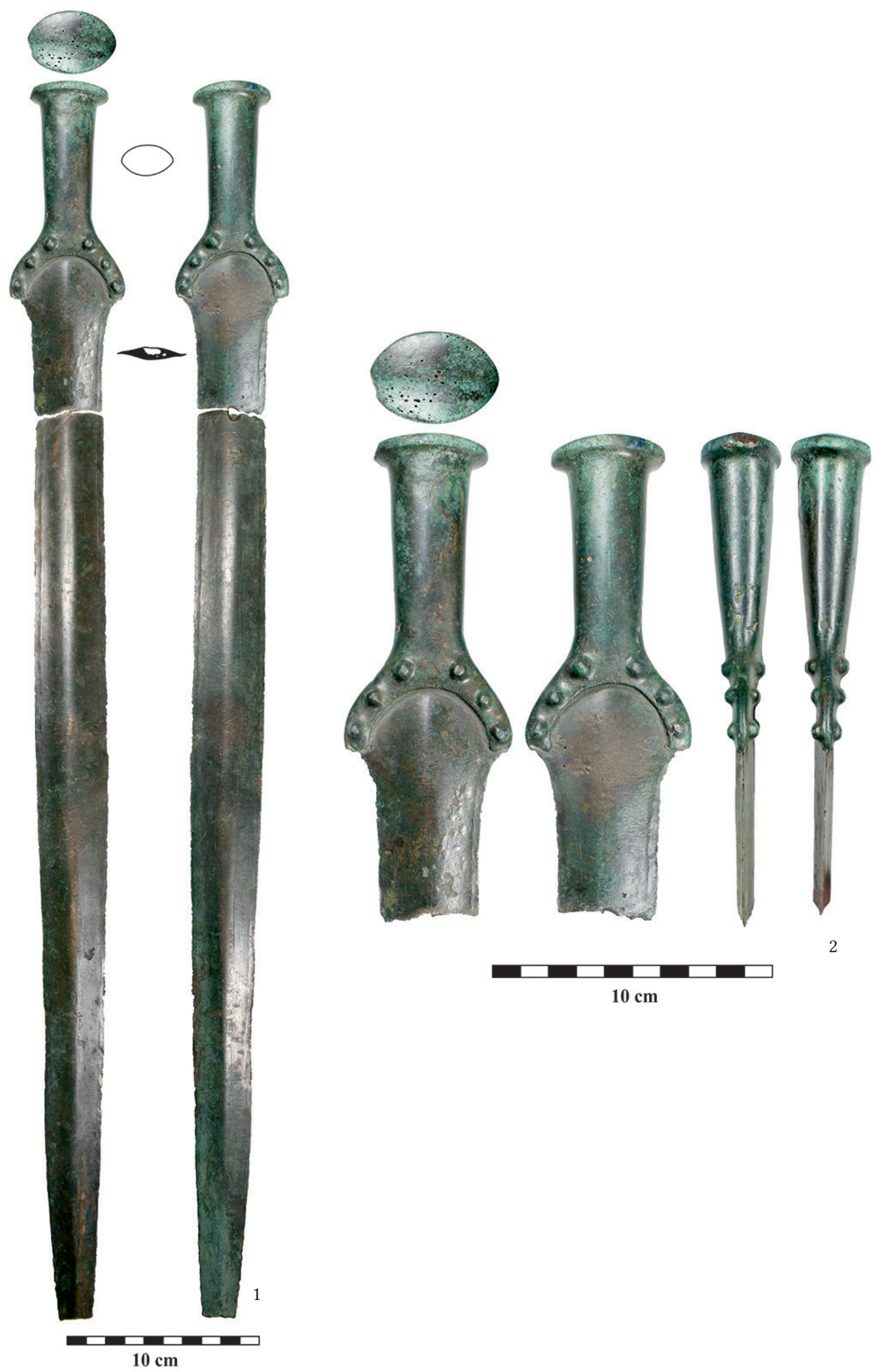

Fig. 2. The sword from Tornyospálca-Sírkútgaz (Szabolcs-Szatmár-Bereg County, HU) (Photo: J. G. Tarbay). 


\section{Typo-chronological remarks}

By looking at this sword, it is immediately apparent that we are dealing with a highly unique object compared to other Carpathian ones (Figs 2-3). It is impossible to find an exact parallel among the swords to this remarkably unusual specimen. One thing is certain: we cannot share the idea of Amália Mozsolics, who probably classified it to the group of swords with octagonal hilts based on the brief information provided by Tibor Kovács. ${ }^{5}$ Such shaping is not visible on this weapon (Figs 2-3). It has an oval-sectioned hilt with rounded edges. It may show some distant similarities with the 'Au swords/C type', as Tibor Kovács has referred to this connection in his report. ${ }^{6}$ Of these weapons perhaps the Simontornya (Tolna County, Hungary) ${ }^{7}$ and one of the Zajta (Szabolcs-Szatmár-Bereg County, Hungary) ${ }^{8}$ swords (No. 2) can be highlighted (Fig. 4; Fig. 10). Originally, both are from hoards which István Bóna, Amália Mozsolics and Tibor Kemenczei associated with the Koszider Period (Br B1). ${ }^{9}$ It should be noted that the above-mentioned swords may be stylistically similar, but the production technology of their metal hilt differs from the Tornyospálca-Sírkútgaz sword (See below).

The Simontornya and Zajta swords were reclassified by Jan-Heinrich Bunnefeld into the so-called Valsømagle group that includes some Austrian, Romanian, Slovakian, Hungarian, and Scandinavian weapons. The latter are dated to Period I, or more precisely, to the Br B period. Three A1 Nordic swords, Velje (Region Syddanmark, Denmark), Valsømagle (Region Sjlland, Denmark), and Overdrevsgård (Allerslev Sogn, Denmark), have a shape that is somewhat similar to the Tornyospálca-Srktgaz specimen. ${ }^{10}$ In South Germany, Ingeborg von Quillfeldt published several Göggenhofen type swords and some individual weapons that can be connected to the Tornyospálca-Sírkútgaz sword,

Mozsolics 1973, 25; Mozsolics 1976, 15; Mozsolics $1985,11$.

6 Holste 1953, 9-12; Kovács 1956; HäNSEl 1968, 29-31; KRÄMER 1985, 9.

7 Holste 1951, 13, Pl. 22,27; Mozsolics 1967, 159-160, Pl. 53,4a; KemenCZei 1991, 12, Pl. 3,9.

8 Mozsolics 1967, 178-179, Pl. 66,3; Kemenczei 1991, 12. Pl. 3,12.

9 Bóna 1958, Fig. 5; Mozsolics 1967, 51-53, 159-160, 178179; KeMENCZEi 1991, 11-12.

10 Holste 1953, Map 3; Lomborg 1959, 84-93, Fig. 21; HäNSEL 1968, Map 1,2; BAdER 1991, 53; BunNeFELD 2016, $53-$ 64, 243, 247, Pl. 2,A11, Pl. 2,A13, Pl. 6,A44, Pl. 121,A11.

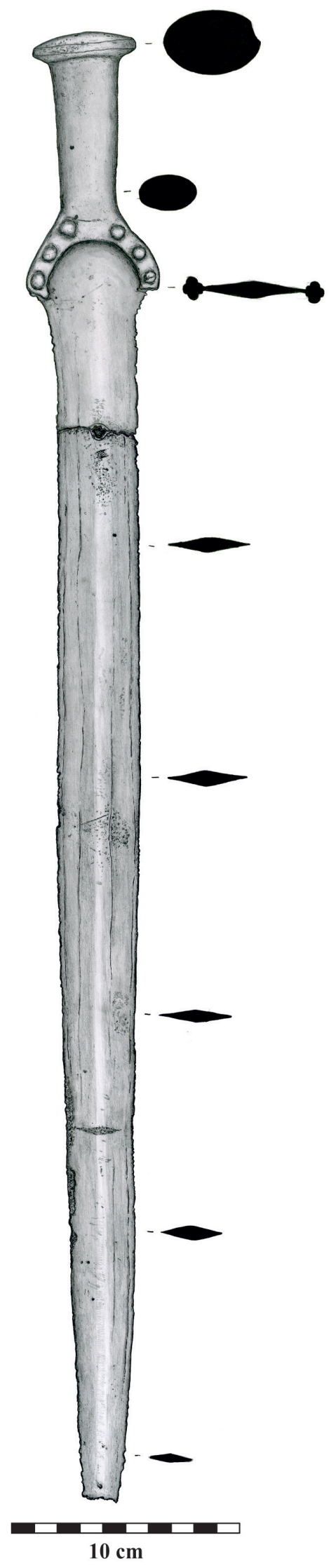

Fig. 3. The sword from TornyospálcaSírkútgaz (Szabolcs-Szatmár-Bereg County, HU) (Drawings: T. Szabadváry). 


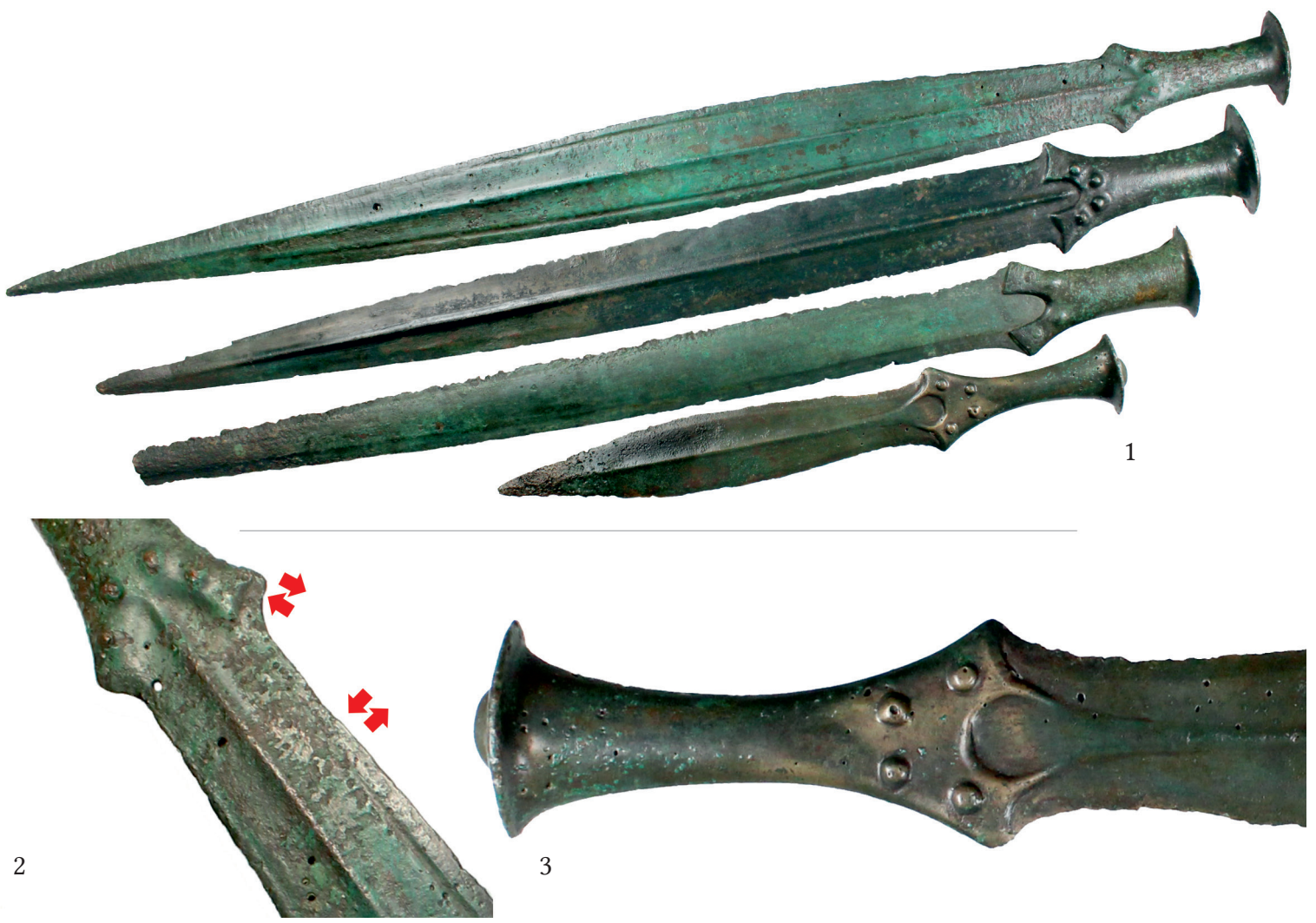

Fig. 4. Metal- and solid-hilted swords from the Zajta hoard (Szabolcs-Szatmár-Bereg County, HU) (Photo: J. G. Tarbay).

based on their blade and hilt construction. Probably the most similar piece to the sword studied is an individual find from the surroundings of Forchheim (Bavaria, Germany), which was found during the construction of the Rhine-Main-Danube canals in Regnitztal. The blade structure is identical, and only minor differences can be observed on the hilt, such as chased patterns, a small, slightly bulging pommel, four pseudo rivets and two pegs. Ingeborg von Quillfeldt could not classify and precisely date this object. Based on the form of the hilt, she related it to the ältere oder mittlere Hügelgräberzeit. ${ }^{11}$ Further parallels to the Tornyospálca-Sírkútgaz sword can also be found among the atypical weapons coming from this region. It is worth mentioning that both the swords from Engstingen [Großengstingen] (Baden-Württemberg, Germany) and Waldshut-Tiengen-Gurtweil (Baden-Württemberg, Germany) have similar pommels to the find studied. Unfortunately, none of them has a datable context. ${ }^{12} \mathrm{~A}$ distant parallel of the Tornyospálca-Sírkútgaz sword is known from Dercolo (Trento Province, Italy), which has a straight blade and a similarly shaped hilt attached by two pegs. The find has no datable context, but Vera Bianco Peroni stylistically related it to the early stage of the Bronzo Medio (Br B1). ${ }^{13}$

The other way to evaluate the Tornyospálca-Sírkútgaz bronze sword is to compare the shape of the handle to Bronze Age metal-hilted daggers. This weapon can be connected to the Krzelów type daggers, particularly with three Polish representatives of this group from Krzelów (Lower Silesian Voivodeship, Poland; beginning of Period II/ Br B1) and Prusiewo burials (Pomeranian Voivodeship, Poland; end of Period I/Br A2), and with an unprovenanced stray find from 'Wielkopolska' [Greater

13 Peroni 1970, 101, Pl. 41,275. 
Poland], published by Marek Gedl. ${ }^{14}$ There is another dagger of the Chodoun type in the Czech Republic, which slightly reminds of the shape of the Tornyospálca sword's hilt. It was found in Praha 6-Bubeneč in an uncertain burial site. Unfortunately, this "assemblage" lacks a datable context. Petr Novák dated the type to between the $\mathrm{Br} \mathrm{B} 1$ and $\mathrm{Br} \mathrm{C}^{15}$

Based on the relative chronological positions of similar swords and daggers, it seems plausible that the sword from Tornyospálca-Sírkútgaz can be dated to the Br B1 (Koszider horizon, 1600-1450 BC), and can be identified as a unique variant of the Valsømagle group.

\section{Metalwork Production and Use-wear Analysis}

The artefact was studied in an unrestored condition, which made it possible to identify modern damage and use-wear traces. Metalwork production and use-wear analysis was carried out by a dnt DigiMicro mobile microscope camera (image sensor 5.0MP CMOS, magnification range $20 \times-500 \times$ ). For the identification of craft and use-wear traces, I have relied on work involved in the archaeometallurgical investigation and experimental analysis of these weapons. ${ }^{16}$ This examination revealed further traces along the surface and cutting edges. On the hilt, different types of minor casting defects can be observed, such as pores on the pommel (Fig. 5,2) and shrinkage defects on the hilt (Fig. 5,1). There is also a larger pore on the (modern) breakage surface of the object (Fig. 2,1). Identical defects were also observed on other Valsømagle swords (see below). ${ }^{17}$ The manufacturing technology of the hilt is a question for future research. Based on visual observations, it seems probable that the hilt was made by cast-on technique, ${ }^{18}$ i.e., first the blade was cast in a two-piece mould, and then the craftsman cast on the hilt part. The separation of the two parts can be best observed along the inner edges of the shoulders. Currently, this is a hypothesis, which must be tested by X-ray/ tomography and elemental composition analysis that can reveal if the parts were separately cast and identify the different elemental compositions of the two parts. This is an important question for the interpretation of this weapon, as the hilts of the local Carpathian swords that belong to the Valsømagle group were manufactured by a different technique. ${ }^{19}$

The cutting edges of the sword were thoroughly hammered (Fig. 6,1; Fig. 7,3). Traces of fine grinding can be observed along the entire blade (Fig. 6; Fig. 7,3; Fig. 8,1). Altogether, these traces suggest that the Tornyospálca-Sírkútgaz sword was a finished product despite its minor casting defects on the hilt and blade. Most likely, the latter did not affect the use of the sword since its breakage occurred when the finder bent it after having discovered the artefact.

The cutting edges of the weapon were examined during the analysis, which revealed different damage types: notches (U-notch), a dent, and curling. Based on previously studied Bronze Age weapons and experimental archaeological combat, all of them can be related to sword fighting. ${ }^{20}$ Dents and notches are the outcome of the blade-on-blade contact of the cutting edges, while curling can be related to a collision with the flat side of another offensive or defensive weapon or any other hard surface. In the case of the Tornyospálca-Sírkútgaz sword, the damage to the weapon is not contemporaneous. Some of it is most probably related to the modern trial of the weapon (dent, curling).

14 GedL 1976, 23-24, Pl. 6,35-37.

15 Novák 2011, 76-77, Pl. 23,318.

16 See Quilliec 2007; Quilliec 2008; SiedlaczeK 2011; Bridgford 2000; Gener 2011; Mödlinger 2011; Molloy 2011; Bunnefeld 2016, 53-63; Bell 2019; Gentile - van Gijn 2019; Hermann et al. 2020.

17 BunNEFELD 2016, 59.

18 See Ersfeld 1990, 40; Armbruster 2000, 85-88.

19 BunNEFELd 2016, 59.

20 See Gentile - van Gijn 2019; Hermann et al. 2020. 
In these cases, the damage was combined with the disturbance of the patina (Fig. 6,1; Fig. 7,2; Fig. 8). There are only a few dents and notches, that can be identified as prehistoric. Except for one dent (Fig. 7,1), most dents are located on the lower part of the blade (Fig. 6; Fig. 7,3). The analysis suggests that the Tornyospálca-Sírkútgaz sword was not only a finished product, but it may have been used in combat, although not as aggressively as in modern times, since the finder certainly tested the capabilities of this bronze weapon.

The current state of the sword is fragmentary. According to the report by Tibor Kovács, the object was brought to the HNM in two pieces (Figs 2-3). ${ }^{21}$ Sándor Agárdi noted that the weapon was broken by the finder, who wanted to bend it when he discovered it. ${ }^{22}$ The modern breakage surface is still visible, which confirms the description provided by Sándor Agárdi. Besides the breakage, there are two signs of additional modern damage on this sword. Part of the pommel has been cut, and the tip is also missing due to breakage (Fig. 2). Based on the above, this object was deposited in an intact state, with the traces of the last combat.

\section{Comparison with the Zajta Weapons}

Similar East Carpathian Valsømagle swords have not been subjected to use-wear analysis before. Thus, to interpret the use-wear data obtained of the Tornyospálca-Sírkútgaz sword, it is essential to study at least some contemporary local weapons. For this brief study, I have selected three swords and one dagger from the Zajta hoard (Szabolcs-Szatmár-Bereg County, Hungary) for comparison (Fig. 4,1; Figs 9-12). Little is known about the circumstances of the discovery of this MBA "assemblage". Although this is a well-known and widely cited Carpathian find, it cannot be considered a secure hoard. The only information about the context of the hoard is that two swords and an axe (Inv. No. 1928.8.1-3) were found in a sand mine and were sent to the HNM by the office of the chief judge [Hung. fóbirói hivatal] in 1928. According to a note in the 1928 inventory book of the HNM, 'two swords' and a disc-butted axe (fokos) were acquired by László Mauthner at the time of discovery. ${ }^{23}$ In 1929, a sword and a dagger, along with a disc-butted axe and a leg/arm spiral were bought from the collector under the provenance of Zajta. ${ }^{24}$ Amália Mozsolics linked three swords, one dagger, one disc-butted axe, and a leg/arm spiral to this hoard. ${ }^{25}$

Below a brief description of each sword is given with the results of the metalwork production and use-wear analysis. The weapons were studied in their restored condition, but fortunately they were not subjected to wet chemical cleaning. The swords were also coated with a layer of an unknown material for protection

No. 1. sword (HNM 1928.8.1): The sword was mostly preserved intact; the fragmentation of its cutting edge can be related to post-depositional processes. From a macroscopic point of view, this is the best executed weapon from the Zajta "hoard". This solid-cast, short sword has a richly ornamented hilt and shiplike depictions along its blade. No surface casting defects can be observed on it. It has four pseudo-rivets and an emphasized midrib. The sword was carefully grinded along its blade. Its cutting edge seems to be slightly hammered. Different types of modern (Fig. 9.K) and presumably prehistoric (Fig. 9.A-f,L) damage (notches/U-notches, worn dent, tip damage, bows, and chipping) can be seen along the weapon's cutting edges. Micro wear traces from prehistoric times densify in the upper half of the blade (Fig. 9). The examination suggests that sword No. 1 can be technologically classified as a finished, used product

21 KovÁcs 1956.

22 AgÁrdi 2003, 21.

23 Inventory Book of the HNM 1928.8; Tompa 1937, 89; Mozsolics 1967, 178.

24 Inventory Book of the HNM 1929.66; Tompa 1937, 89; Mozsolics 1967, 178.

25 Tompa 1937, 89; Mozsolics 1967, 178-179; KemenCzei 1991, 12, Pl. 2,10-13; David 2002, 475, H 173. 
deposited in an intact state after use. Dimensions: length $639.75 \mathrm{~mm}$; length (handle) $120.09 \mathrm{~mm}$; diameter (disc) $61.25 \times 37.76 \mathrm{~mm}$; diameter (handle) $27.37 \times 12.13 \mathrm{~mm}$; width (shoulders) $60.49 \mathrm{~mm}$; thickness (blade) $48.42 \times 7.80$ mm; weight 795.7 g (Fig. 4,1; Fig. 9).

No. 2. sword (HNM 1928.8.2): Sword No. 2 was studied in a restored state. It was originally deposited in an intact state. The breakage of the tip, as well as the heavy fragmentation of one of the cutting edges are modern. This sword can be cited as a loose parallel to the Tornyospálca-Sírkútgaz specimen. In fact, there are few similarities between the two weapons. The metal hilt parts of the Zajta sword No. 2 were cast as two identical elements which were assembled and attached to the blade by two hammered pegs (Fig. 10,F). The craftsman also added two pseudo-rivets to the shoulders to mimic the style of solid-cast swords. In this case, the sword hilt was also richly decorated with chased ornaments. From a macroscopical point of view, the blade also seems to be well manufactured, probably hammered along the edges. Based on the microscopic traces, it was heavily ground (Fig. 10,D). Along the cutting edges of the weapon, different types of modern (Fig. 10,B-C) and plausible prehistoric damage (notches, curling, and dents) (Fig. 10,A,D-E, $G-I$ ) were observed, caused by the cutting edge and flat surfaces of another bladed weapon. Prehistoric damage was concentrated on the lower half of the blade (Fig. 10). It should be noted that they were only visible on one of the cutting edges because of the heavy fragmentation of the other. From a technological point of view, sword No. 2 can be identified as a finished, used product that is deposited in an intact state after use. Dimensions: length $584 \mathrm{~mm}$; length (handle) $102.54 \mathrm{~mm}$; diameter (disc) $51.11 \times 35.04 \mathrm{~mm}$; diameter (handle) $27.70 \times 17.85 \mathrm{~mm}$; width (shoulders) $51.49 \mathrm{~mm}$; thickness $39.61 \times 4.77 \mathrm{~mm}$; weight $507.6 \mathrm{~g}$ (Fig. 4,1; Fig. 10).

No. 3. dagger (HNM 1929.66.2): Dagger No. 3 is in a restored state and coated with a protective layer. It is a large, solid-cast dagger, imitating real-size swords. It has a stepped pommel, four pseudo rivets, and a leaf-shaped blade with an emphasized midrib. Hammering traces are visible along its cutting edges. However, traces of shrinkage porosity (Fig. 11,E-F) are visible on/near its hilt. Along the cutting edges, modern dents, a U-notch (Fig. 11,A-B), a prehistoric dent (Fig. 11,D) and tip damage (Fig. 11,C) were identified. Dagger No. 3 can be interpreted as a finished, used product deposited in an intact state after use. Length $343 \mathrm{~mm}$; length (handle) $117.95 \mathrm{~mm}$; diameter (disc) $44.25 \times 28.89 \mathrm{~mm}$; diameter (handle) $17.87 \times 9.92 \mathrm{~mm}$; width (shoulders) $45.54 \mathrm{~mm}$; thickness $40.98 \times 4.81 \mathrm{~mm}$; weight $324.8 \mathrm{~g}$ (Fig. 4,1,3; Fig. 11).

No. 4. sword (HNM 1929.66.1): Sword No. 4 was deposited in an intact state; its fragmented condition is due to post depositional phenomena. From a typological point of view, sword No. 4 seems to be a well-crafted weapon. It is decorated with dense lines and cross-hatched triangles along its hilt and a rich motif consisting of boot-shaped bundles of lines and dots along the middle of the blade. The craftsman also decorated its pommel. Cast design elements can also be observed, like four pseudo rivet heads along the shoulders of the hilt, an emphasized midrib, and a rather wide outline groove along the cutting edge. Like so many weapons, the surface of the cast was carefully ground. However, taking a closer look, it became apparent that this sword may not be as masterfully cast as it seems. Particularly close to the hilt, several pores can be detected that seem to have been caused by shrinkage porosity (Fig. 4,2; Fig. 12,H). Some of these pores are so large that they would have been visible to a Bronze Age man. These defects are analogous to those of Tornyospálca-Sírkútgaz sword. Close to the hilt, a defect hinting at an amateur can be identified, i.e., an extreme mismatch, which was caused by the unwanted shift of the mould parts during casting (Fig. 4,2). In this case, the mismatch defect heavily affected the physical properties of the sword. The leaf-shaped blade became much larger than planned, and it caused the blade to be asymmetrical on one side. The microscope camera revealed several modern (Fig. 12,D-E,G) and some prehistoric dents (Fig. 12,A-C,F). The bending of the tip can also be considered modern. The analysis suggests that this weapon can be defined as a finished, used, low casting quality product deposited in an intact state. Length $721.87 \mathrm{~mm}$; length (handle) $108.69 \mathrm{~mm}$; diameter (disc) $52.54 \times 27.32 \mathrm{~mm}$; diameter (handle) $25.17 \times 11.30 \mathrm{~mm}$; width (shoulders) 48.69 mm; thickness $54.40 \times 7.08$ mm; weight 803.1 g (Fig. 4,1-2; Fig. 12).

The results of the analysis can be summarized as follows. The Zajta weapons were made by two different casting technologies. Three of them were solid casts, which were made with two-pieced stone or ceramic moulds (Nos 1, 3-4). The trace of this technology can be observed on specimen No. 4. It shows a mismatch defect caused by the displacement of the moulds during casting. The blade of No. 2 was also cast in a two-pieced mould, but its hilt plates were separately cast, probably by lost-wax casting technique. After casting, they were attached to the blade by two pegs. ${ }^{26}$ Based on 
the presence of fine decorations, grinding traces, and hammering along the cutting edges of some of the studied specimens, the three swords (Nos 1-2, 4) and the dagger (No. 3) can be classified as finished, usable products. However, there is a difference in casting quality. While Nos 1 and 2 are fine products, showing no traces of surface casting defects, on No. 3 and No. 4 analogous traces of shrinkage porosity to the Tornyospálca-Sírkútgaz sword can be observed. By considering production and use-wear traces, this damage might not have affected the usage of the weapons. However, as it has been mentioned, the mismatch caused a much wider blade in the case of sword No. 4 than planned. This is more than a simple aesthetical defect because it certainly affected the physical properties and, through this, the usage of the weapon.

The four weapons had ergonomic handles, which were made in different sizes but in a uniform style. The blades differed from each other, No. 1 and No. 4 had a leaf-shaped blade with an emphasized midrib. This design appeared also on dagger No. 3. Sword No. 2 had a straight blade like the Tornyospálca-Sírkútgaz sword. Except for No. 1, prehistoric micro damage was observed on the lower half of the weapons' blade. This must have been caused by blade-on-blade contact with another bladed weapon. Damage related to thrusting was only visible on the dagger (No. 3). The prehistoric damage (notches, dents) observed on the Zajta swords is analogous to the TornyospálcaSírkútgaz specimen. It is important to note that modern damage was also present on all specimens, which is due to the unfortunate likelihood that the finders tried using these weapons. As David R. Bell has illustrated with several Irish Bronze Age examples, the modern reuse of swords is not rare at all. ${ }^{27}$ A fine local analogue for this unfortunate fact is the second Tornyospálca sword found in 1971. According to Sándor Agárdi, this specimen was turned into a "pig-killing knife" by the locals who found it. ${ }^{28}$ The Tornyospálca and Zajta weapons are emblematic examples of the extent to which the macroscopic and microscopic properties of weapons can be transformed by the finders. Considering the modern effects, the deposition condition of the Zajta weapons can be reconstructed as intact in all cases. Their fragmented cutting edges and broken parts are due to post-depositional phenomena and intentional damage caused by the finders.

Based on the metalwork production and use-wear analysis, the four weapons were deposited in an intact state without any kind of breakage or manipulation. They had different casting qualities, but they were all manufactured as finished products. The traces of the last combat were not removed from their blades before deposition. The types of damage suggest that they were applied in parrying situations against another bladed weapon and were mostly used for slashing and defensive movements. Evidence for thrusting was only observed on the large dagger. It can also be concluded that the deposition condition, some of the observed technological traces, as well as the use-wear phenomenon of the Zajta weapons are analogous to the Tornyospálca-Sírkútgaz specimen.

\section{Conclusions}

It can be concluded that the Tornyospálca-Sírkútgaz sword was a finished product with minor casting defects. It was manufactured completely and used during the MBA, Koszider period (1600-1450 BC). This object was originally deposited in an intact state, and at that time, the traces of the last prehistoric combat were still visible along its cutting edges. This damage can be identified as caused by blade-on-blade contact that occurred during a fight against another bladed weapon, probably a sword or a long dagger. At the time of discovery, the state of the object was heavily altered by

28 AgÁRdi 2003, 21. 
the finder, who bent the object and broke it into two parts. There is additional damage that could also have been caused by him, such as the breakage of the tip and the cutting mark on the pommel. Based on modern micro damage observed along the cutting edge, the weapon appears to have been tried by someone.

For comparison, contemporaneous weapons, three swords and one dagger from Zajta, were studied by the same metalwork production and use-wear analysis to compare their craft and usage traces to the Tornyospálca-Sírkútgaz weapon. After the identification of modern effects that altered the condition and cutting edges of these weapons, a similar deposition condition to the sword in question was reconstructed for the Zajta finds. It can be concluded that they were finished, used products deposited in an intact state without breakage or any other type of manipulation. Their cutting edges showed several, prehistoric micro combat traces resulting from blade-on-blade contact. It is noteworthy that in the case of the dagger, a thrusting trace was also revealed. The presence of these marks suggests that a combat event happened before the deposition. These traces of damage were intentionally not removed from the cutting edges, which is a standard process in the maintenance of any kind of bladed weapon or tool. Thus, damage was important to the depositors because it probably carried some sort of additional symbolic meaning. It is logical to assume that they were mementos of a combat event, which may have been connected indirectly (selection of weapons after a battle or combat) or directly (ritual combat in the framework of deposition) to the hoarding act.

This line of thought is linked to the interpretation of the Tornyospálca-Sírkútgaz sword because combat traces were present on this weapon as well. It is unfortunate that the exact context and find spot of this sword is unknown. However, it can be assumed that this object was found in a hoard like the rest of the Northeast Carpathian Koszider period swords. ${ }^{29}$ It is also a plausible scenario that it was placed in a hoard in a mixed composition, probably along with other weapons like the Zajta hoard. There may be a small chance of finding this hypothetical assemblage in the Sírkútgaz owing to the precise topographical description Tibor Kovács left for future research. The present analysis suggests that this weapon was taken out of circulation after combat. The typological connections of the find are quite interesting because the formal characteristics of this weapon do not resemble the local Carpathian swords. They are more likely to be related to the representatives of the Valsømagle group that were found outside this region, and to certain dagger types originating from Poland and the Czech Republic. Since swords were personalized during the Bronze Age, the individual objects followed the stylistic taste, fighting style, and physical characteristics of their owner (size of their hands, length of their arms, etc.). We can assume that the combatant who wielded the Tornyospálca-Sírkútgaz sword was perhaps not born in this region. This individual might have been defeated in a battle here, or he could have served as a "foreign" mercenary of a local tribe or chief. In my opinion, these are plausible scenarios. However, they are hypothetical as they cannot be studied by satisfactory archaeological methods in the case of the Tornyospálca-Sírkútgaz sword due to its context. But it is possible to further refine the current results by further systematic field research of the Sírkútgaz and by the in-depth archaeometallurgical analysis of the weapon with particular attention to the provenance of its raw material and its comparison to the rest of the Valsømagle swords and to other contemporaneous Carpathian weapons and bronzes from the Koszider period. 


\section{Acknowledgements}

I am grateful to János Dani for sending me a key book for my work. I am also indebted to László Szende and Béla Debreczeni-Droppán for kindly providing me with archive documents on the circumstances of the discovery of this sword. Finally, I would like to express my gratitude to Tamás Szabadváry for the drawings of the Tornyospálca-Sírkútgaz sword.

The paper is part of Project No. 134910, which has been implemented with support provided by the National Research, Development, and Innovation Fund of Hungary, financed under the PD_2020 funding scheme.

\section{Sources}

KovÁcs, T. 1956: Jelentés a Tornyospálcán és Kisvárdán 1965 november 4-5-én végzett kiszállásról. Archive Document of the HNM no. XXII.389/1956.

\section{References}

AgÁRDI, S. 2003: Suhogó Idő. Emlékek, adatok, dokumentumok. Tornyospálca község múltjából. Tornyospálca.

Armbruster, B. R. 2000: Goldschmiedekunst und Bronzetechnik. Studien zum Metallhandwerk der Atlantischen Bronzezeit auf der Iberischen Halbinsel. Monographies instrumentum 15. Montagnac.

BADER, T. 1991: Die Schwerter in Rumänien. Prähistorische Bronzefunde IV/8. Stuttgart.

BELL, R. D. 2019: A shifting chronology of combat damage: Reassessing the evidence for use and reuse on Irish Bronze Age swords. In: Knight, M. G. - Bsoughton, D. - Wilkinson, R. E. (eds): Objects of the Past in the Past. Investigating the significance of earlier artefacts in later contexts. Oxford, 152-180.

BónA, I. 1958: Chronologie der Hortfunde vom Koszider-Typus. Acta Archaeologica Academiae Scientiarum Hungaricae 9, 211-243.

BunNefELD, J.-H. 2016: Älterbronzezeitliche Vollgriffschwerter in Dänemark und Schleswig-Holstein. Studien zu Form, Verzierung, Technik und Funktion. Studien zur nordeuropäischen Bronzezeit 3. Mainz.

BRIDGFORD, D. D. 2000: Weapons, Warfare and Society in Britain 1250-750 BC. Phd Thesis, University of Sheffield, Sheffield.

DAvid, W. 2002: Studien zu Ornamentik und Datierung der bronzezeitlichen Depotfundgruppe Hajdúsámson-Apa-Ighiel-Zajta. Bibliotheca Musei Apulensis 18. Alba Iulia.

ERsfeld, J. 1990: Formen und Giessen. Restaurierung und Museumstechnik 3. Weimar.

GEdL, M. 1976: Die Dolche und Stabdolche in Polen. Prähistorische Bronzefunde VI/4. München.

Gener, M. 2011: Integrating form, function and technology in ancient swords. The concept of quality. In: Uckelmann, M. - Mödlinger, M. (eds): Bronze Age Warfare: Manufacture and Use of Weaponry. British Archaeological Reports - International Series 2255. Oxford, 117-123.

Gentile, V. - van Gijn, A. 2019: Anatomy of a notch. An in-depth experimental investigation and interpretation of combat traces on Bronze Age swords. Journal of Archaeological Science 105, 130-143. DOI: 10.1016/j.jas.2019.02.004

HÄNsEL, B. 1968: Beiträge zur Chronologie der mittleren Bronzezeit im Karpatenbecken. Beiträge zur Ur- und Frühgeschichtlichen Archäologie des Mittelmeer-Kulturraumes 7. Bonn.

Hermann, R. - Crellin, R. J. C. - Uckelmann, M. - Wang, Q. - Dolfini, A. 2020: Bronze Age Combat: An experimental approach. British Archaeological Reports - International Series 30, Oxford. DOI: 10.30861/9781407355719

Holste, F. 1951: Hortfunde Südosteuropas. Marburg/Lahn. 
Holste, F. 1953: Die Bronzezeitlichen Vollgriffschwerter Bayerns. München.

KemenczeI, T. 1988: Die Schwerter in Ungarn I (Griffplatten-, Griffangel- und Griffzungenschwerter). Prähistorische Bronzefunde IV/6. München.

KemenczeI, T. 1991: Die Schwerter in Ungarn II. (Vollgriffschwerter). Prähistorische Bronzefunde IV/9. Stuttgart.

Lomborg, E. 1959: Donauländische Kulturbezeihungen und die Relative Chronologie der frühen nordischen Bronzezeit. Acta Archaeologica København, 51-139.

Krämer, W. 1985: Die Vollgriffschwerter in Österreich und der Schweiz. Prähistorische Bronzefunde IV/10. München.

Mozsolics, A. 1967: Bronzefunde des Karpatenbeckens. Depotfundhorizonte von Hajdúsámson und Kosziderpadlás. Budapest.

Mozsolics, A. 1973: Bronze- und Goldfunde des Karpatenbeckens. Depotfundhorizonte von Forró und Ópályi. Budapest.

Mozsolics, A. 1976: Ein Achtkantgriffschwert von Dunaújváros. Alba Regia 15, 9-23.

Mozsolics, A. 1985: Bronzefunde aus Ungarn. Depotfundhorizonte von Aranyos, Kurd und Gyermely. Budapest.

MöDlinger, M. 2011: Herstellung und Verwendung bronzezeitlicher Schwerter Mitteleuropas. Eine vertiefende Studie zur mittelbronze- und urnenfelderzeitlichen Bewaffnung und Sozialstruktur. Universitätsforschungen zur prähistorischen Archäologie 193. Bonn.

Molloy, B. P. C. 2011: Use-wear analysis and use-patterns of Bronze Age Swords. In: Uckelmann, M. Mödlinger, M. (eds): Bronze Age Warfare: Manufacture and Use of Weaponry. British Archaeological Reports - International Series 2255. Oxford, 67-84.

NovÁk, P. 2011: Die Dolche in Tschechien. Prähistorische Bronzefunde VI/13. Stuttgart.

Peroni, V. B. 1970: Die Schwerter in Italien (Le spade nell'Italia continentale). Prähistorische Bronzefunde IV/1. München.

SiedlaczeK, M. 2011: Der experimentelle Nachguss von bronzezeitlichen Schwertern. Experimentelle Archäologie in Europa 10, 109-119.

ToмPA, F. 1937: 25 Jahre Urgeschichtsforschung in Ungarn 1912-1936. Bericht der Römisch-Germanischen Komission 24-25, 27-127. DOI: 10.11588/berrgk.1937.0.35643

Quilliec, B. T. 2007: Technologie des épées à l'Age du Bronze final en Europe atlantique: reconstitution des chaînes opératoires. In: Évin, J. (dir.): Un siècle de construction du discours scientifique en préhistoire. XXVI Congrès Préhistorique de France, Congrès du Centenaire de la Société Préhistorique Française, Avignon, 21-25 Septembre 2004. Paris, 401-411.

Quilliec, B. T. 2008: Use, Wear and Damage: Treatment of Bronze Swords before Deposition. In: Hamen, C. Quilliec, B. (eds): Hoards from the Neolithic to the Metal Ages: technical and codified practices. British Archaeological Reports: International Series 1758, Oxford, 67-78.

von QuillfeldT, I. 1995: Die Vollgriffschwerter in Süddeutschland. Prähistorische Bronzefunde IV/11. Stuttgart.

(C) 2022 The Author(s).

cc) (1) This is an open-access article distributed under the terms of the Creative Commons Attribution-Non Commercial 4.0 International Licence (CC BY-NC 4.0). 

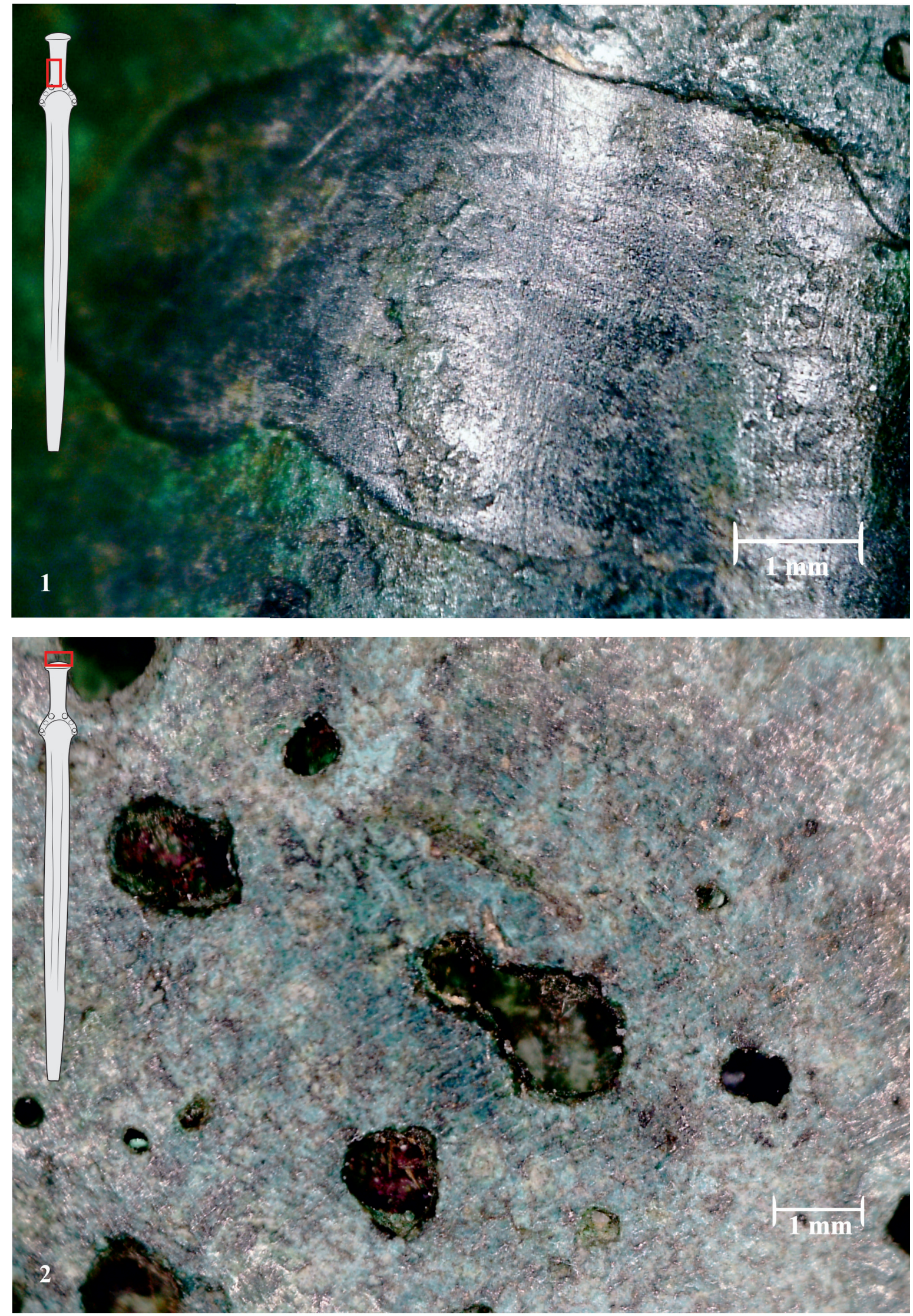

Fig. 5. Production traces (Tornyospálca-Sírkútgaz). 1 - shrinkage, 2 - shrinkage porosity (Micrographs: J. G. Tarbay). 

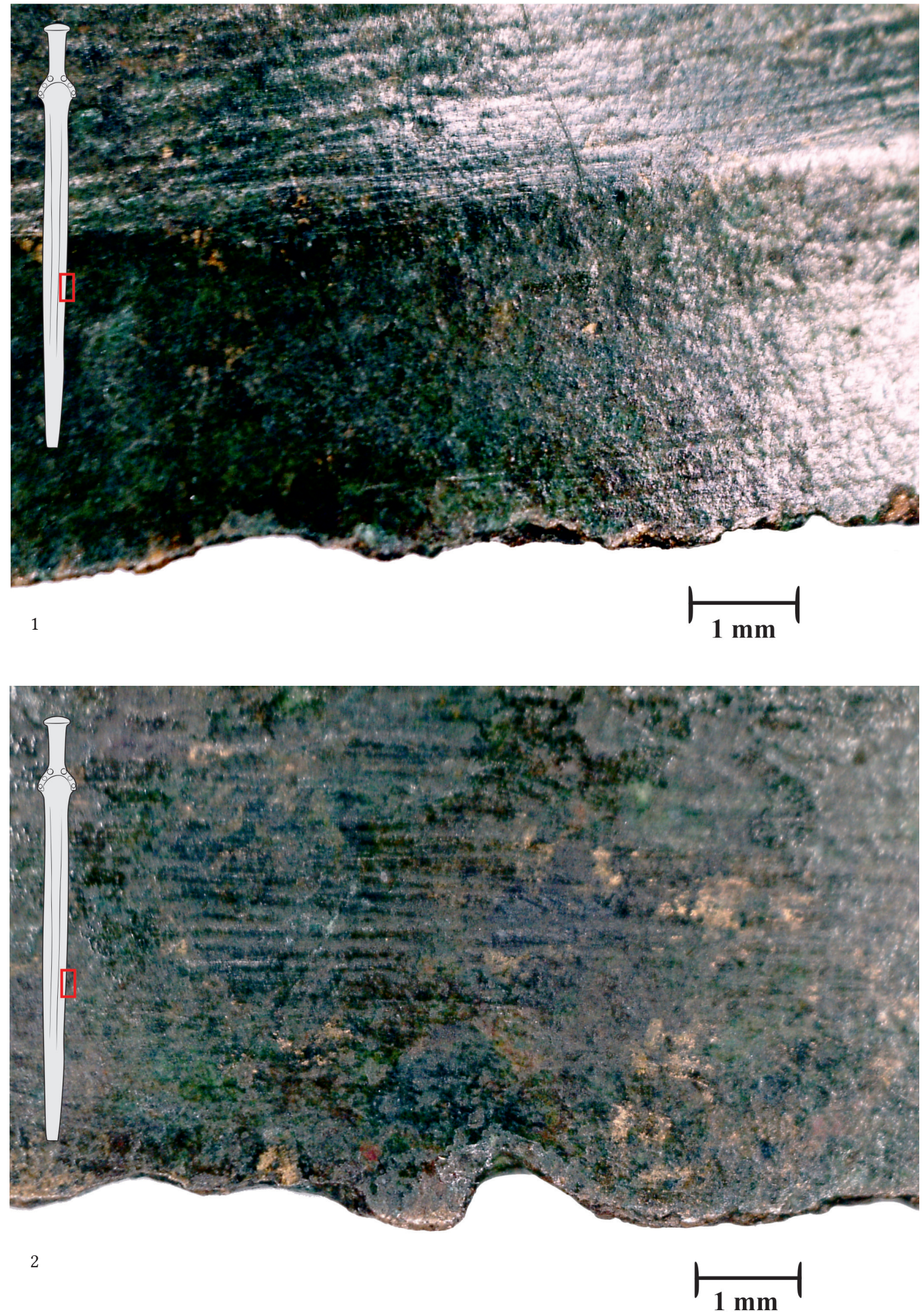

Fig. 6. Production and use-wear traces (Tornyospálca-Sírkútgaz). 1 - griding traces and a hammered, fragmented cutting edge with a dent, 2 - grinding traces on the blade and an U-shaped notch (Micrographs: J. G. Tarbay). 

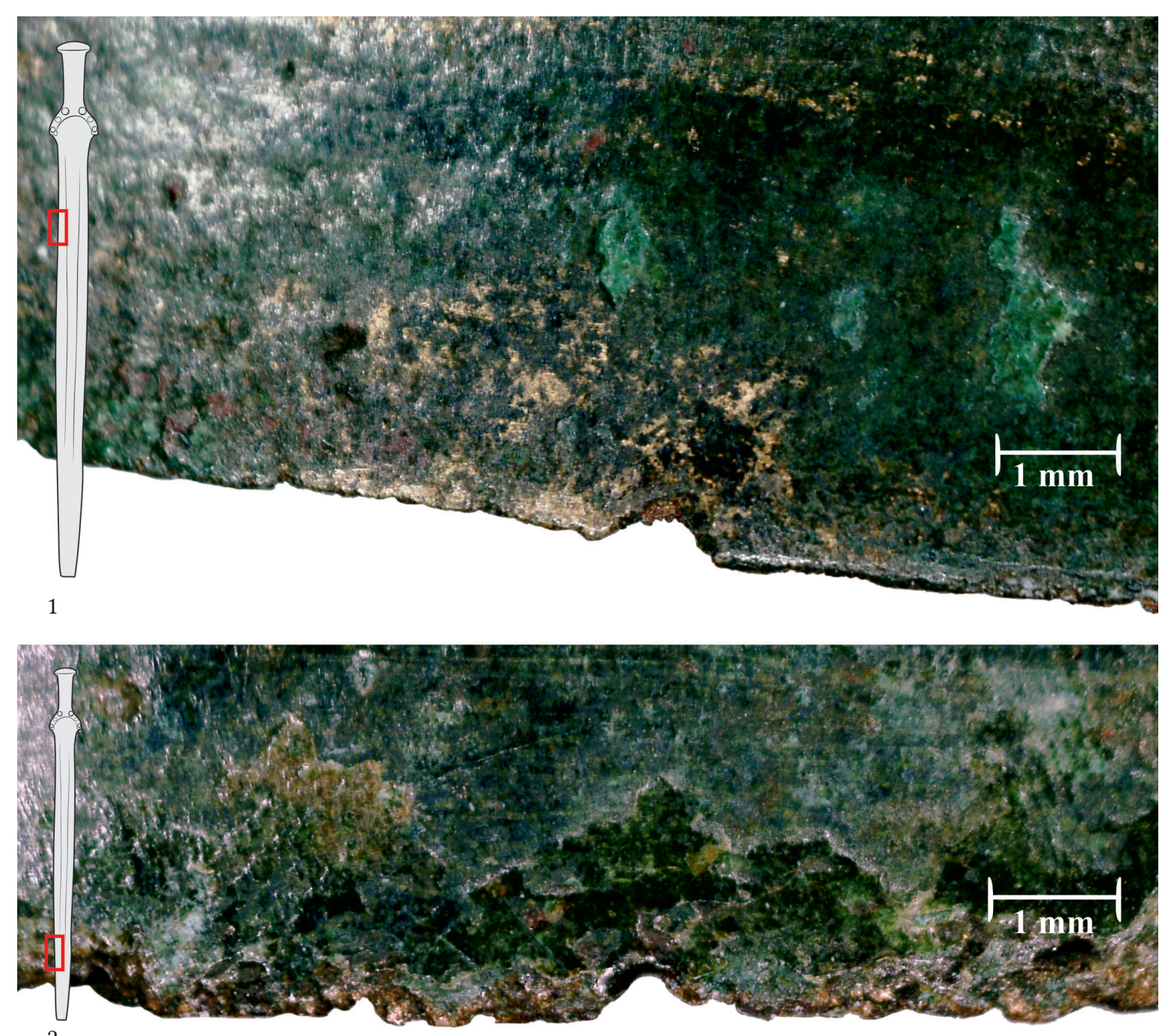

2

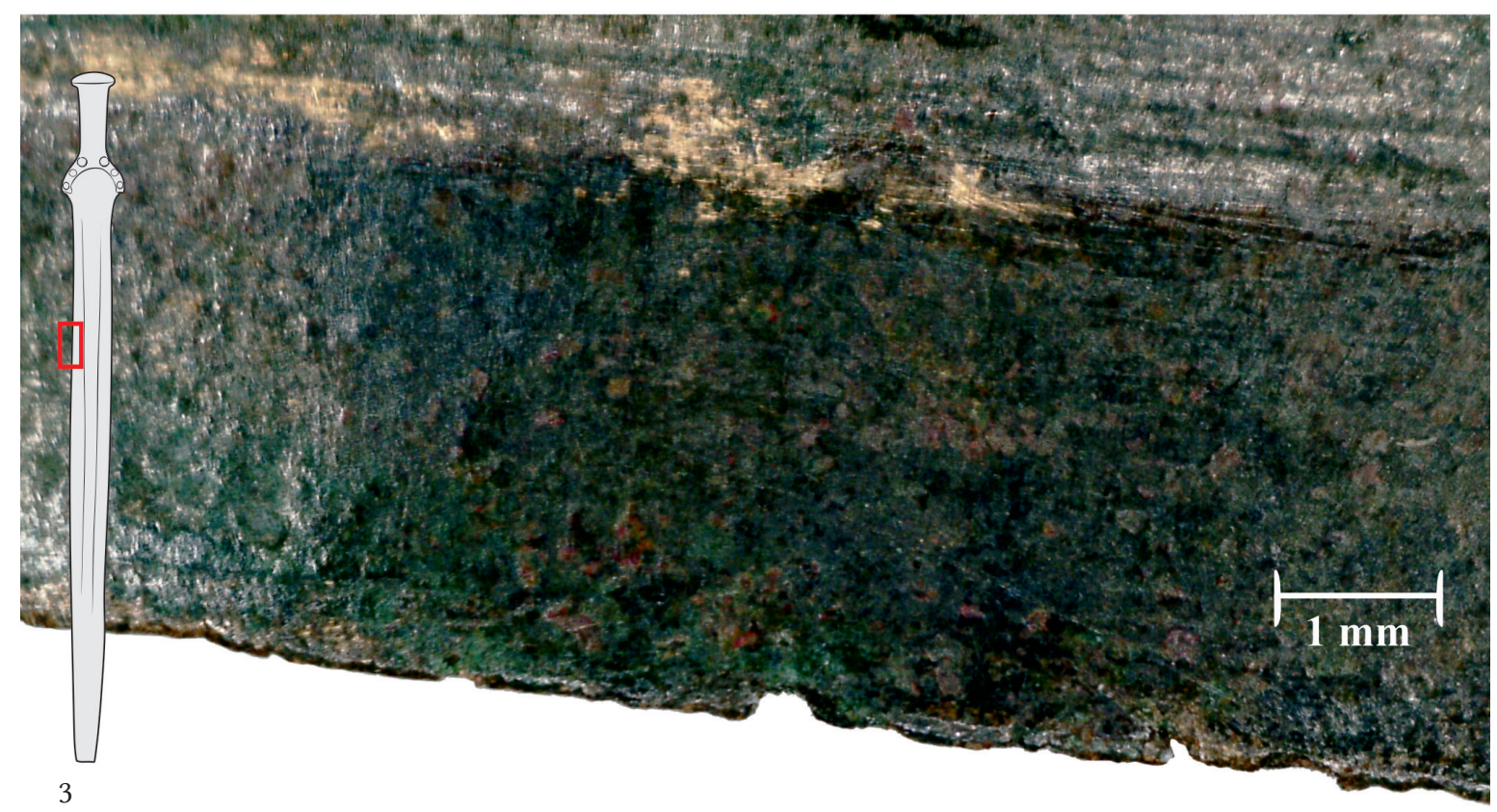

Fig. 7. Production and use-wear traces (Tornyospálca-Sírkútgaz). 1 - notch, 2 - bow and modern dents, 3 - grinding traces and a hammered cutting edge with an U-notch (Micrographs: J. G. Tarbay). 

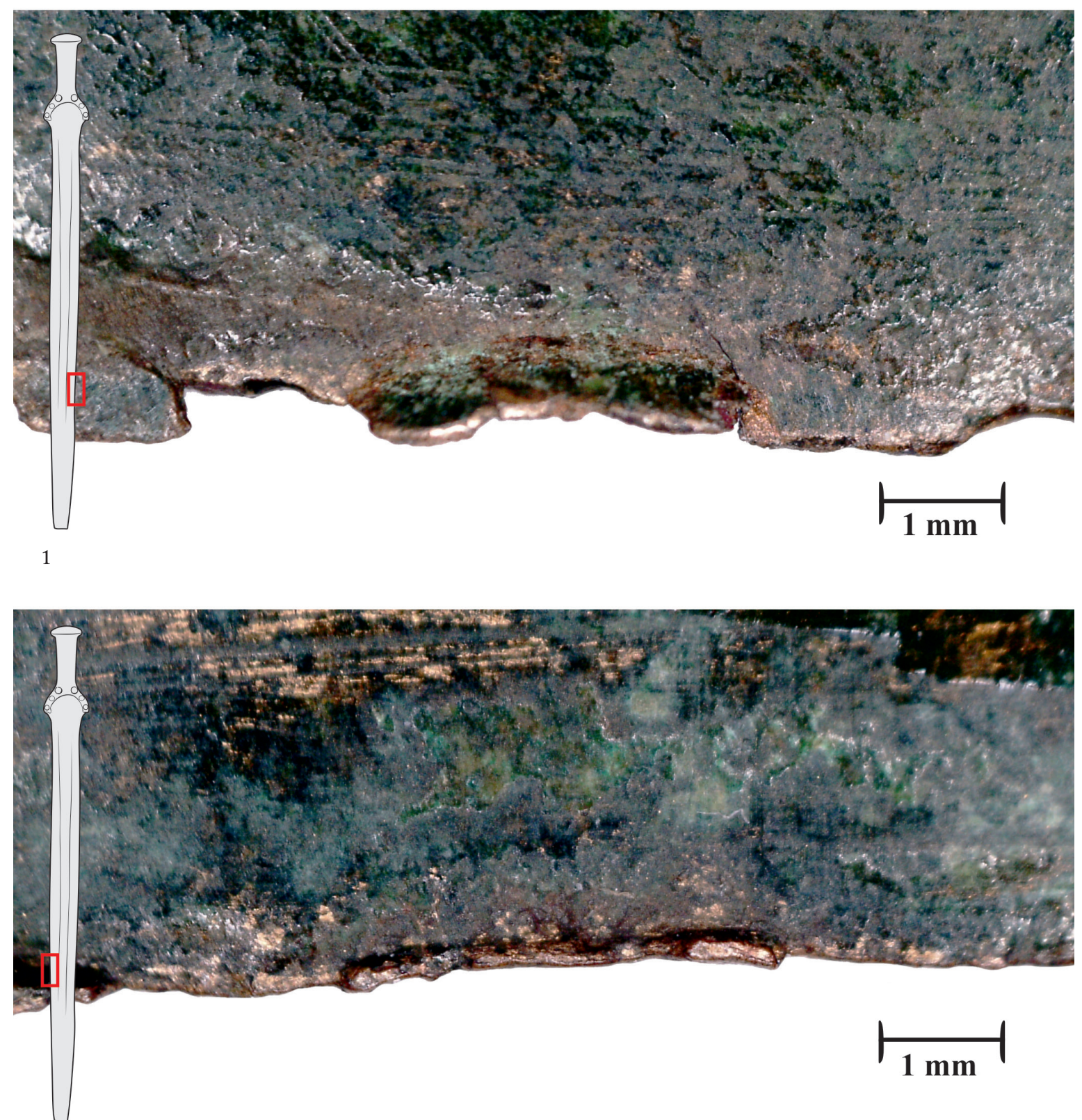

2

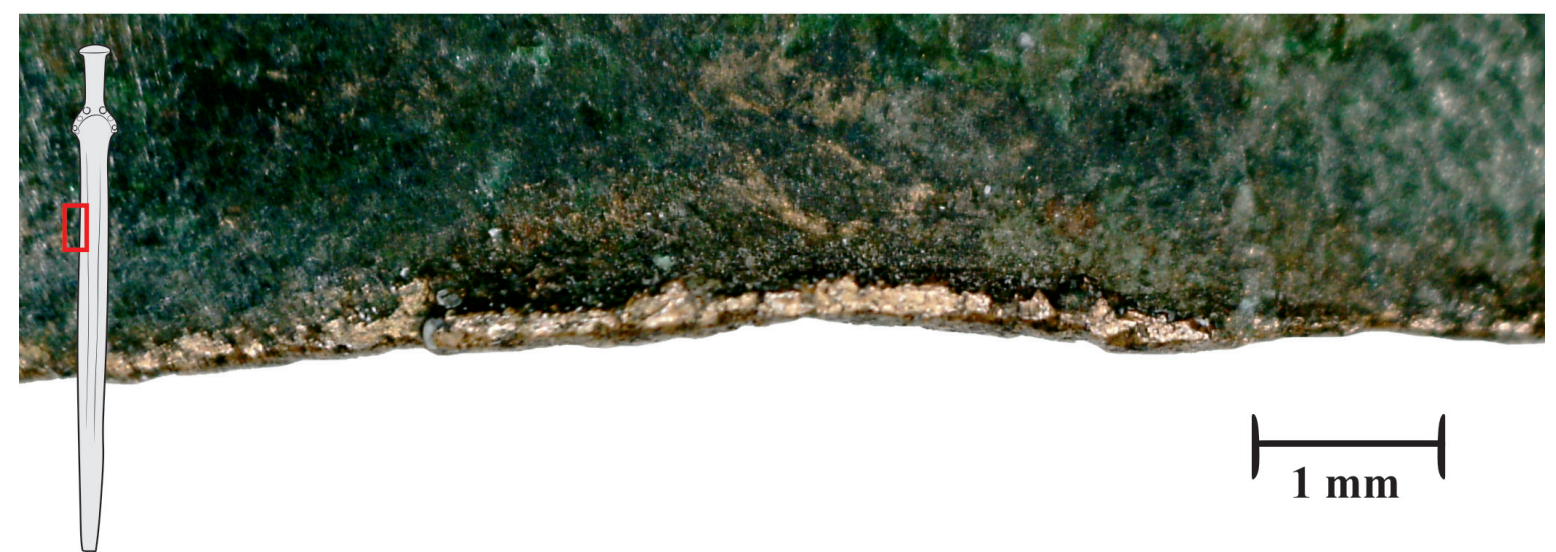

3

Fig. 8. Production and use-wear traces (Tornyospálca-Sírkútgaz). 1 - grinding traces and a modern damage along the cutting edge, 2-3 - modern curling (Micrographs: J. G. Tarbay). 

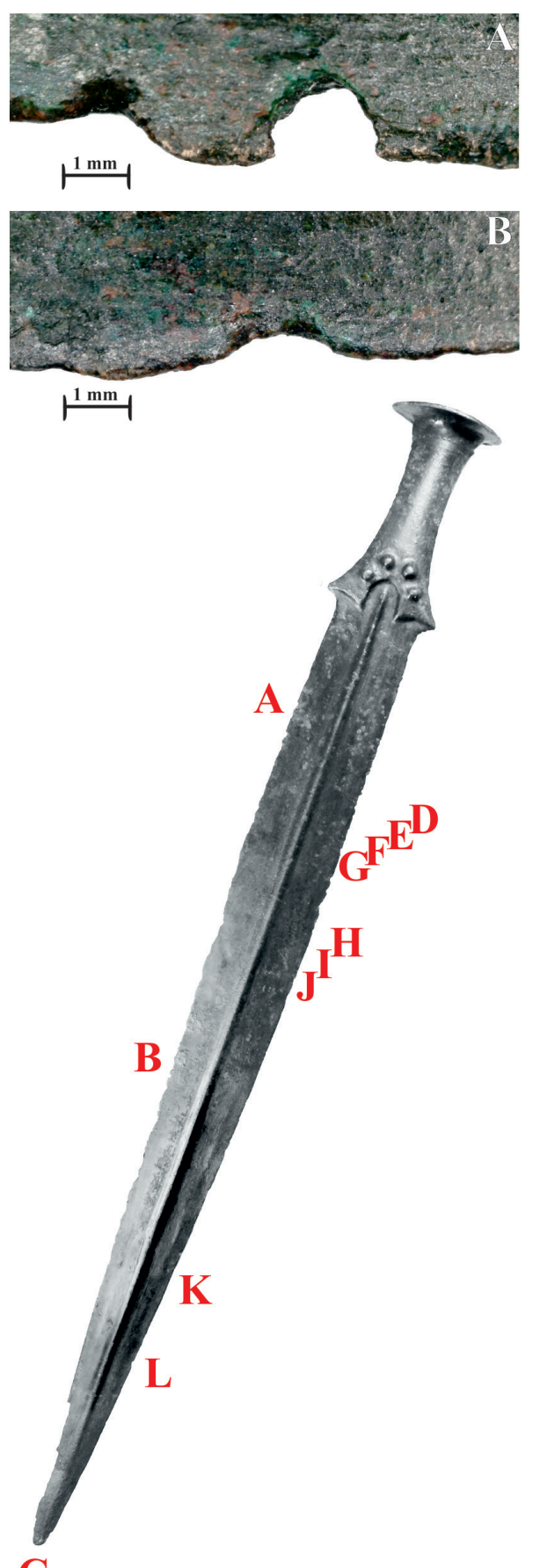

C

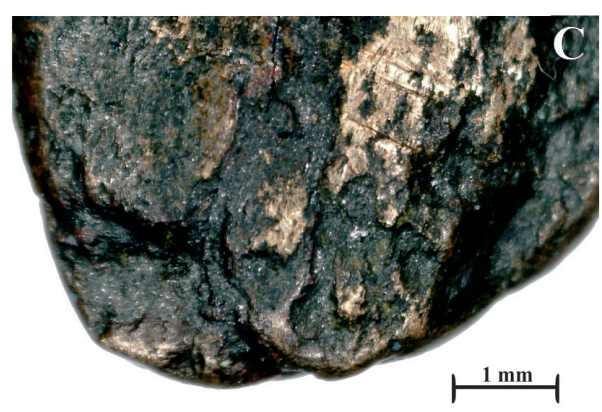

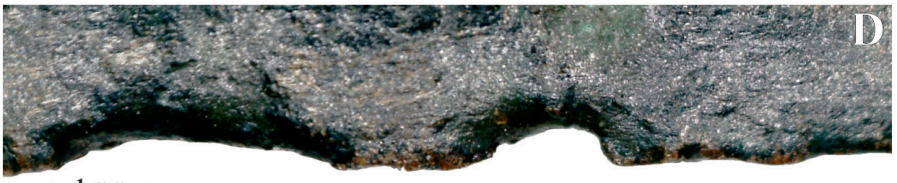

$\stackrel{1 \mathrm{~mm}}{\longmapsto}$

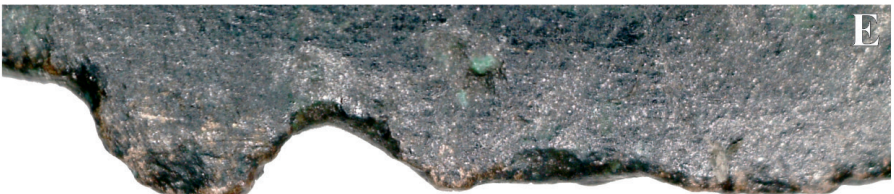

$1 \mathrm{~mm}$

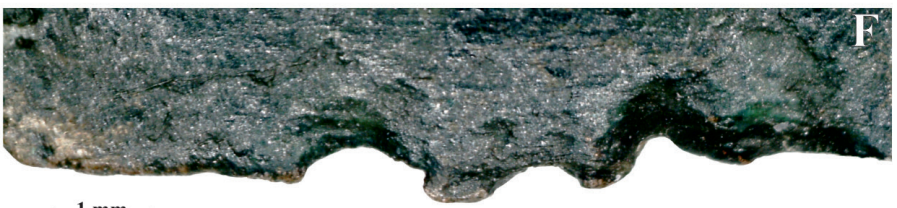

$$
11 \mathrm{~mm}
$$
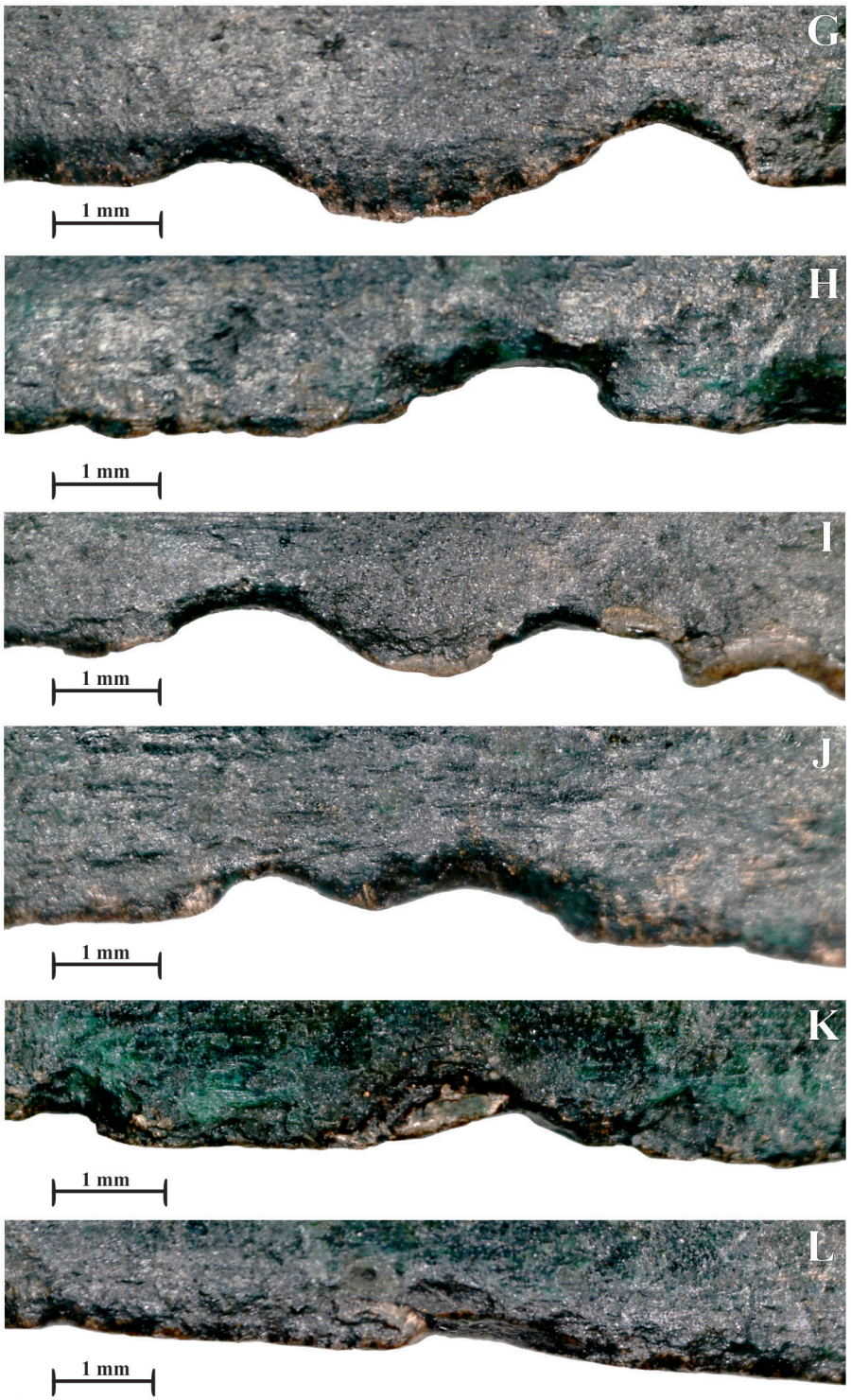

Fig. 9. Use-wear traces (Zajta, no. 1). A - U-notch, B - worn dent, C - tip damage (modern?), D-J - notches, $\mathrm{K}$ - dent and modern bow, L - chipping (Micrographs: J. G. Tarbay). 

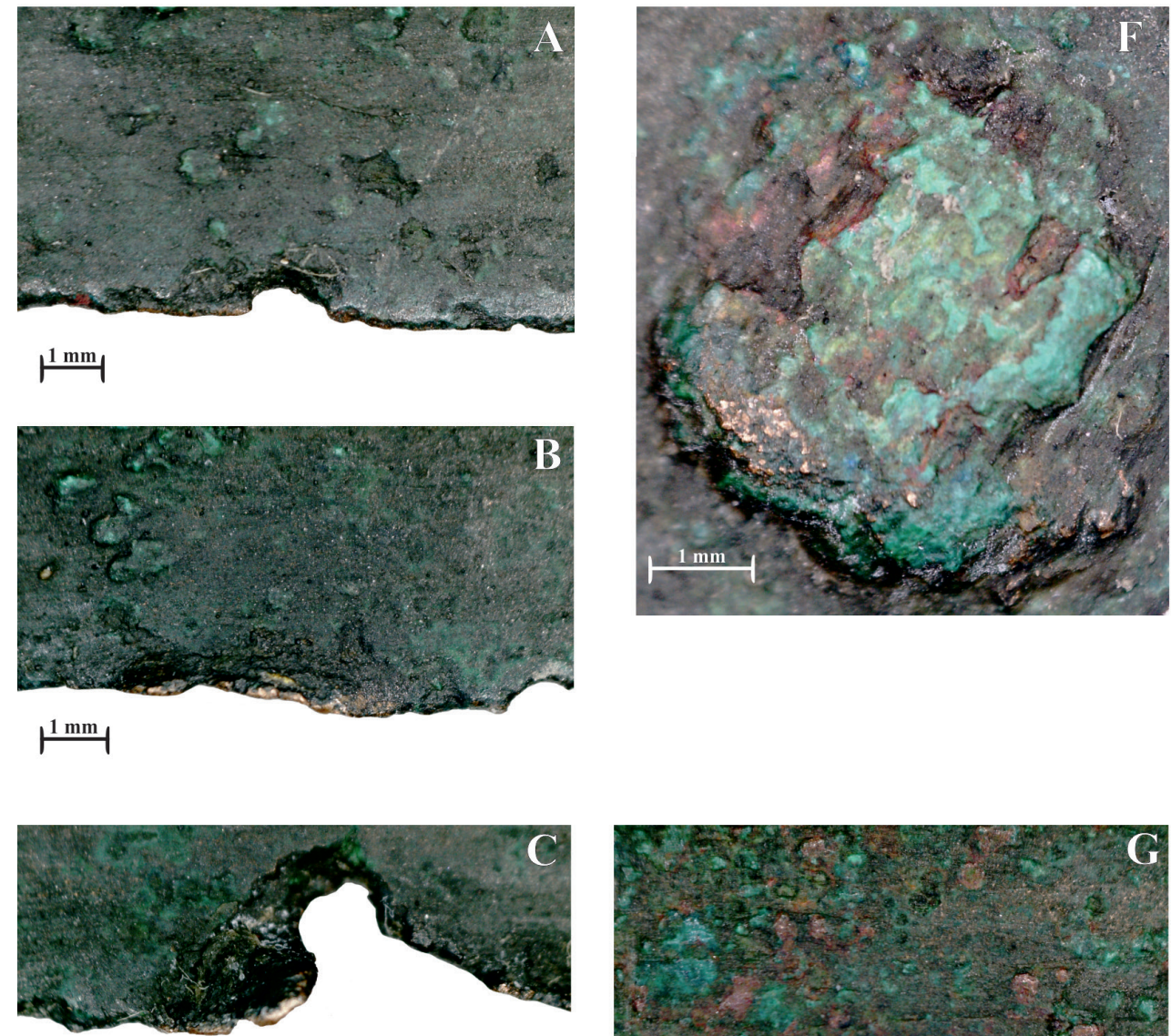

$1 \mathrm{~mm}$
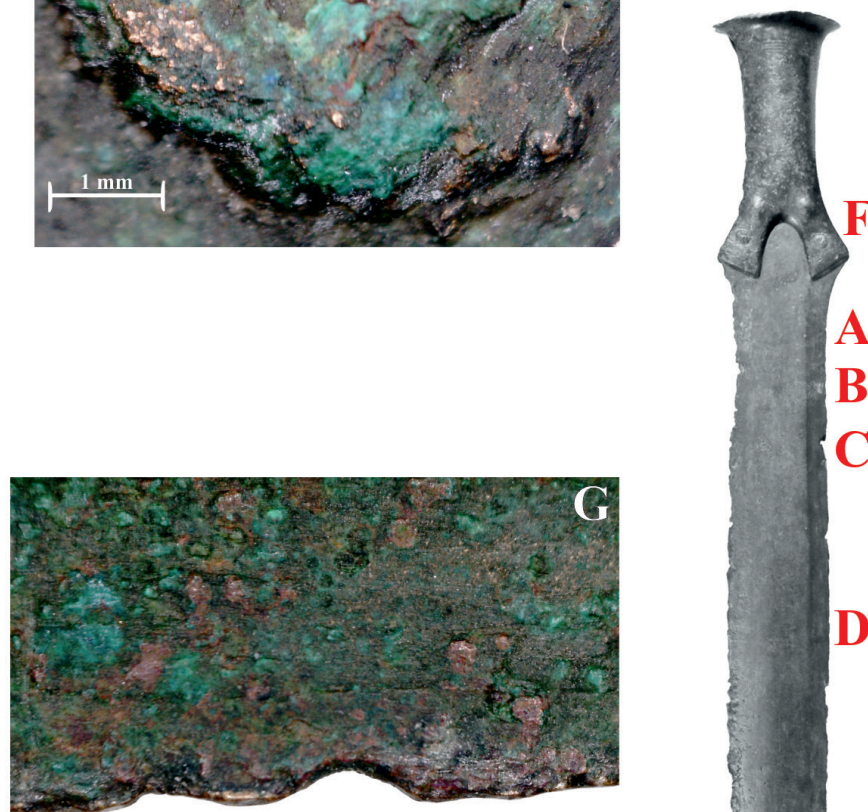

A

B

C

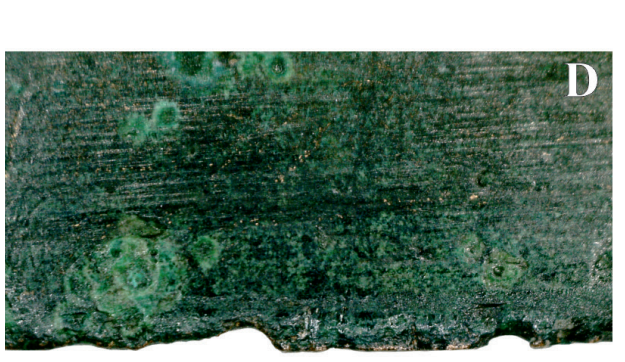

$1 \mathrm{~mm}$

$\stackrel{1 \mathrm{~mm}}{1}$

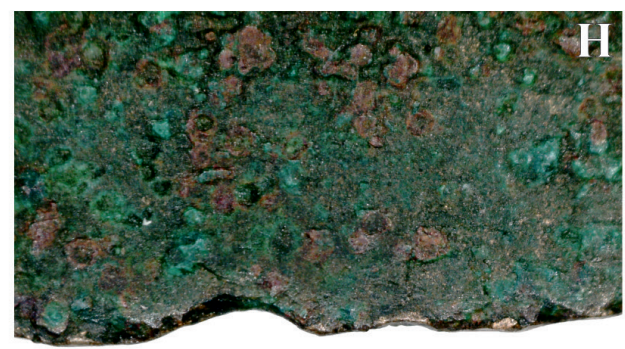

E

G

H

D

$1 \mathrm{~mm}$

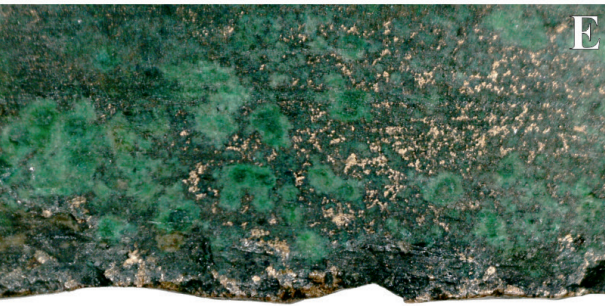

$1 \mathrm{~mm}$

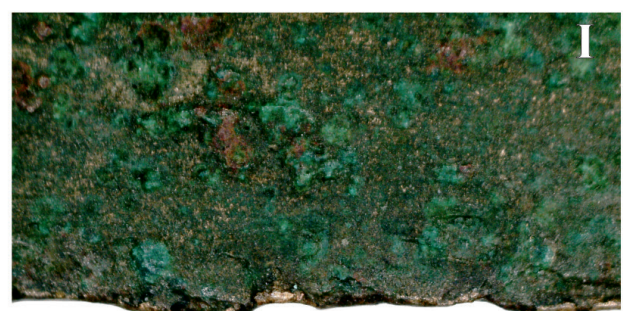

$1 \mathrm{~mm}$

Fig. 10. Production and use-wear traces (Zajta, no. 2): A - notch, B - modern curling, C - modern notch, D - grinding traces and dents, E - dents, F - peg, G-I - dents (Micrographs: J. G. Tarbay). 

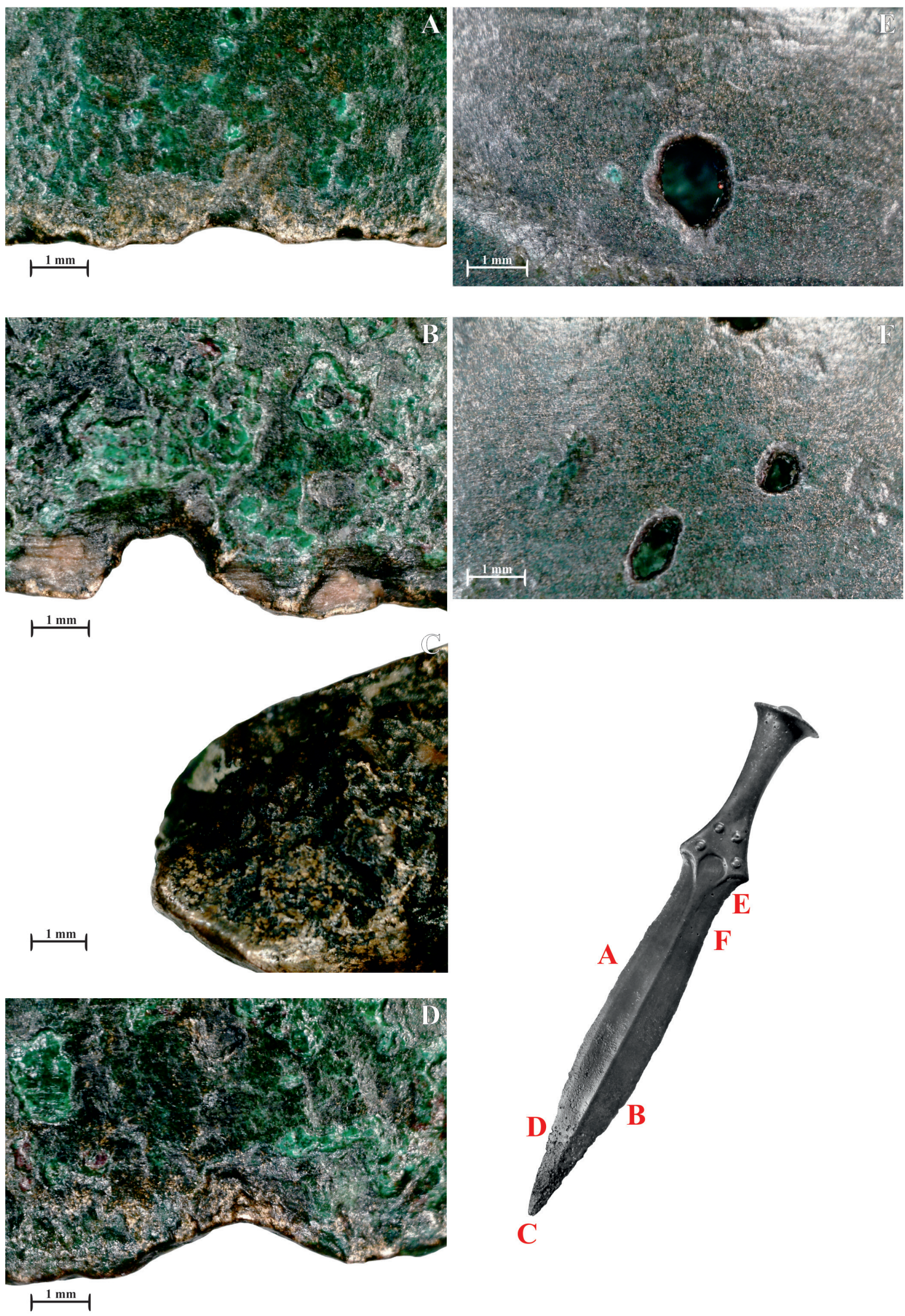

Fig. 11. Production and use-wear traces (Zajta, no. 3). A - modern dents, B - modern U-notches, C - rounded tip, D - dent, E-F - shrinkage porosity (Micrographs: J. G. Tarbay). 

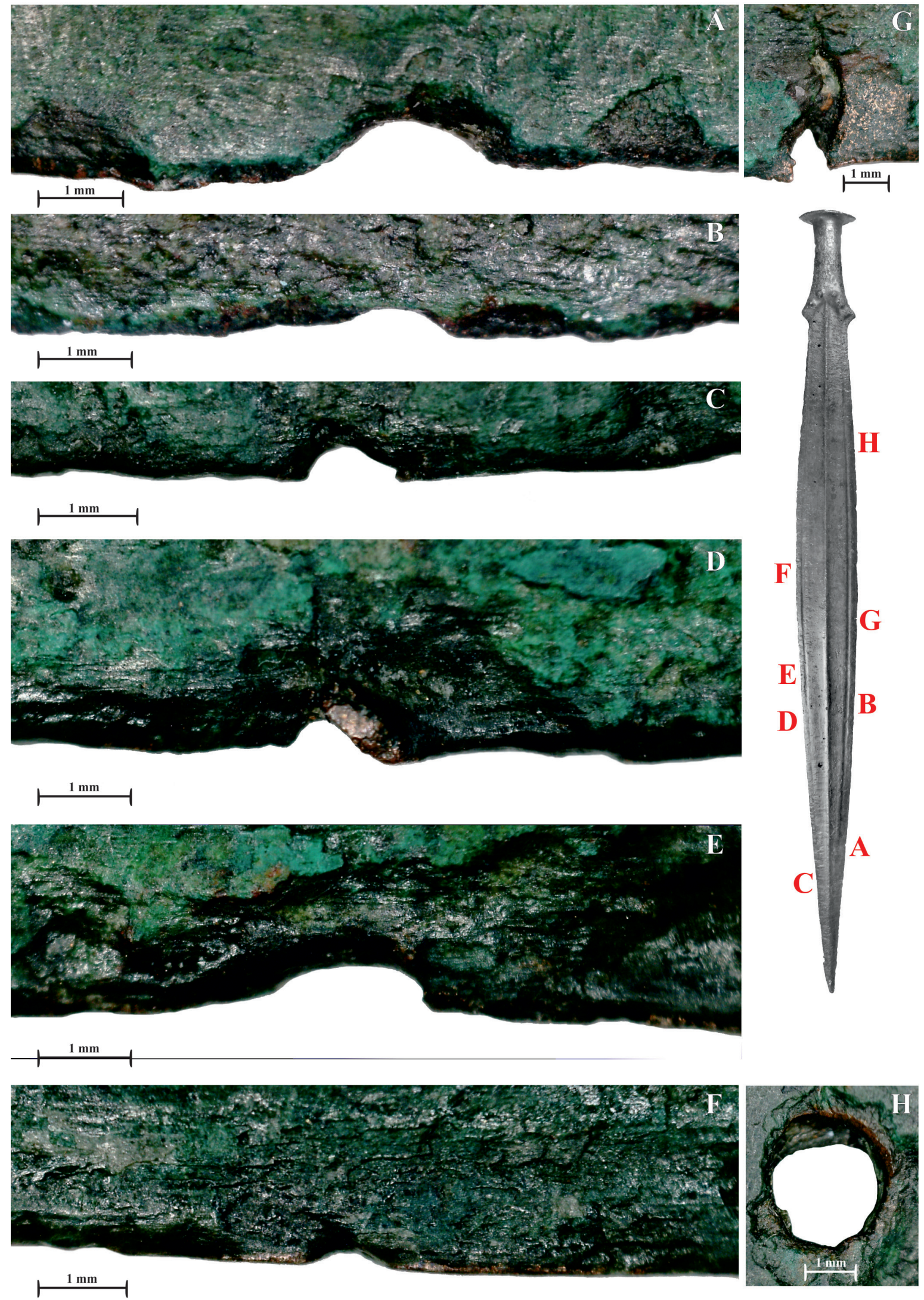

Fig. 12. Production and use-wear traces (Zajta, no. 4). A-C - dents, D-E - modern damages, F - dent, $\mathrm{G}$ - modern damage, $\mathrm{H}$ - pore (Micrographs: J. G. Tarbay). 